\title{
PERFIL Y SITUACIÓN DE LOS PRODUCTORES QUE INTEGRAN LOS TIANGUIS Y MERCADOS ORGÁNICOS EN MÉXICO
}

\author{
PROFILE AND SITUATION OF PRODUCERS WHO FORM THE STREET \\ AND ORGANIC MARKETS IN MEXICO
}

Tzatzil I. Bustamante-Lara ${ }^{1^{*}}$, Rita Schwentesius-Rindermann ${ }^{2}$

\begin{abstract}
${ }^{1}$ División de Ciencias Sociales y Administrativas Campus Celaya-Salvatierra. Universidad de Guanajuato. (tzatzi.bustamante@gmail.com). ${ }^{2}$ Profesora del Centro de Investigaciones Interdisciplinarias para el Desarrollo Rural Integral (CIIDRI) de la Universidad Autónoma Chapingo (rschwentesius@prodigy.net)
\end{abstract}

\section{RESUMEN}

En México, la agricultura orgánica inició en los años sesenta; desde entonces, ha crecido incluso en época de crisis. Es un sistema de producción que puede tener resultados positivos tanto en el ingreso de los pequeńos agricultores, asalariados rurales e incluso en el desarrollo rural. En México, a partir de 1994 surgieron los tianguis y mercados enfocados hacia lo orgánico. Se dieron como iniciativa de productores y consumidores, y desde entonces han sido una alternativa para la sostenibilidad económica de los pequeños productores que los integran. Se presenta una revisión bibliográfica sobre la agricultura orgánica, qué es, cuándo y cómo surgió, cuál ha sido su desarrollo, y qué sistemas garantizan su calidad de orgánico en México. Se menciona también la sostenibilidad y su carácter multidisciplinario. Posteriormente, y a través de los resultados obtenidos de la aplicación de 52 encuestas dirigidas a productores de diferentes tianguis y mercados orgánicos, se muestra su perfil, su situación respecto a: producción, comercialización, certificación orgánica y sostenibilidad económica, la cual aumenta a medida que los productores amplían su producción, diversifican sus canales de comercialización y cuentan con un certificado orgánico.

Palabras clave: agricultura orgánica, sistemas de garantía, sostenibilidad económica.

\section{INTRODUCCIÓN}

L a agricultura es un conjunto de técnicas y conocimientos desarrollados para cultivar la tierra. Se constituye por todas las acciones que el humano pueda llevar a cabo para transformar el

* Autor responsable $*$ Author for correspondence.

Recibido: mayo, 2015. Aprobado: agosto, 2017.

Publicado como ARTÍCULO en ASyD 15: 507-530. 2018.

\section{Abstract}

In México, organic agriculture began in the seventies; since then, it has grown even in times of crisis. It is a production system that may have positive results in the income of small-scale farmers, rural paid workers, and even in rural development. In Mexico, since 1994, street and organic markets emerged. They arose as an initiative of producers and consumers, and since then they have been an alternative for the economic sustainability of the small-scale producers that form them. A bibliographic review about organic agriculture is presented: what it is, when and how it arose, what has been its development, and what systems ensure the organic quality in Mexico. Sustainability and its multidisciplinary character are also mentioned. Later, and through the results obtained from the application of 52 surveys directed towards producers from different street and organic markets, their profile is shown, their situation regarding production, commercialization, organic certification and economic sustainability, which increases as the producers increase their production, diversify their commercialization channels and have an organic certificate.

Key words: organic agriculture, guarantee systems, economic sustainability.

\section{INTRODUCTION}

griculture is a set of techniques and knowledge
developed to cultivate land. It is constituted
by all the actions that humans can carry out to transform the natural environment. Its main purpose is the exploitation of resources originated by the land and favored by the action of man (Sáenz, 2009).

Throughout time, agriculture has developed in various ways, which has caused for there to be different 
medio ambiente natural. Su propósito principal es la explotación de los recursos originados por la tierra y favorecidos por la acción del hombre (Sáenz, 2009).

A lo largo del tiempo la agricultura se ha desarrollado de diversas formas, lo cual ha ocasionado que existan diversos tipos de la misma. Estos se basan primordialmente en cuatro factores. El primero es, según su dependencia al agua. El segundo implica la magnitud de la producción y su relación con el mercado. Posteriormente, según la obtención del máximo rendimiento, o bien, de la mínima utilización de recursos u otros medios de producción y, finalmente, se basa el método y los objetivos de producción.

Aunque estos tipos de agricultura son diversos, el debate principal se da respecto a los métodos y objetivos sobre los cuales se lleva a cabo esta actividad, los cuales pueden contenerse dentro de cuatro vertientes como se muestra en el Cuadro 1.

El enfoque de este trabajo se da entre la agricultura orgánica y la convencional. En el caso de la primera, la International Federation of Organic Agriculture Movements (IFOAM) la considera como ${ }^{3}$ : "un sistema de producción que mantiene la salud de los suelos, los ecosistemas y las personas. Se basa en los procesos ecológicos, la biodiversidad y los ciclos adaptados a las condiciones locales, en lugar de la utilización de insumos con efectos adversos. Agricultura orgánica combina tradición, innovación y la ciencia para beneficiar el medio ambiente compartido y promover relaciones justas y una buena calidad de vida para todos los involucrados".

Cuadro 1. Vertientes de los sistemas de producción agrícola. Table 1. Aspects of the agricultural production systems.

Tipo de agricultura

Agricultura tradicional

Agricultura convencional, industrial o moderna

Agricultura orgánica

Agricultura natural, integrada o mixta types. These are based primordially on four factors. The first is according to their dependency on water. The second implies the magnitude of the production and its relationship with the market. Then, according to the ability of obtaining the maximum yield, or else, the minimum use of resources or other means of production; and, finally, based on the method and the objectives of production.

Although these types of agriculture are diverse, the main debate takes place around the methods and objectives about which this activity is carried out, which may be contained within four aspects as shown in Table 1 .

The approach of this study is between organic and conventional agriculture. In the case of the first, the International Federation of Organic Agriculture

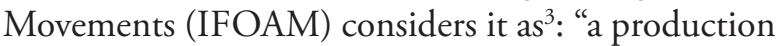
system that maintains the health of soils, ecosystems and people. It is based on ecological processes, biodiversity and the cycles adapted to local conditions, instead of the use of inputs with adverse effects. Organic agriculture combines tradition, innovation and science to benefit the shared environment and promote just relations and a good quality of life for everyone involved".

In turn, conventional agriculture is known as a system that implements processes that allow increasing the speed of agriculture with the aim of increasing the production and the availability of foods per person (Gómez, 2000; Altieri and Nicholls, 2000). This system was based primarily in four schools. The first indicated the need for
Fuente: elaboración propia con base en diversos autores. Source: authors' elaboration based on various authors.
Es todo tipo de agricultura antes de la revolución verde (1920) (Gómez, 2000).

Cambió el modelo agrícola mediante la implementación de: paquetes tecnológicos intensivos, mecanización, mejoramiento genético y desarrollo de agroquímicos para el control de plagas, enfermedades y malezas (Altieri y Nicholls, 2000).

"Es un sistema de producción que se basa en procesos ecológicos, biodiversidad y ciclos adaptados, combinando tradición, innovación y ciencia para beneficiar el medio ambiente y a la sociedad" (IFOAM, 2008).

Es la combinación de la agricultura orgánica y la convencional, con el plus de la conciencia ambiental y la salud (Rendón, 2004). 
Por su parte, la agricultura convencional se conoce como un sistema que lleva a cabo procesos que permiten incrementar la rapidez de la agricultura con el fin de aumentar la producción y la disponibilidad de alimentos por persona (Gómez, 2000; Altieri y Nicholls, 2000). Este sistema se basó principalmente en cuatro escuelas. La primera indicaba la necesidad de especialización. Por lo tanto, científicos y agrónomos comenzaron a ignorar la necesidad de integración de un sistema de manera holística. La segunda escuela se enfocó en la supervivencia del más apto, poniendo más atención en la competencia y creando una falla en la naturaleza en la que hay más cooperación e interacción. Posteriormente, se dio la tercera aproximación hacia la agricultura convencional. Esta se basó en la teoría de Justus Von Liebig (considerado el padre de la fertilización química), que indica que siempre habrá un factor que limitará la producción, y a fin de que la productividad aumente se debe vencer este factor. La cuarta escuela se basó en las teorías de Malthus, quien afirmaba que el crecimiento de la población es exponencial, mientras que la producción de alimentos es aritmética. Por lo tanto, habría algún punto en el que la gente pasaría hambrunas y la solución consistía en producir más (SOCLA Y TWIN, 2015). De manera concreta, ambas difieren en diversos temas.

Entonces, según sus métodos y objetivos, la agricultura orgánica es un sistema alternativo al convencional como se muentra en el Cuadro 2. Tiene specialization. Therefore, scientists and agronomists began to ignore the need for integration of a system in a holistic manner. The second school was focused on the survival of the fittest, placing more attention on the competition and creating a fault in nature where there is more cooperation and interaction. Then, the third approximation towards conventional agriculture emerged. This was based on the theory by Justus Von Liebig (considered the father of chemical fertilization), indicating that there will always be a factor that will limit production, and that this factor should be overcome in order for productivity to increase. The fourth school was based on Malthus' theories, who stated that population growth is exponential, while food production is arithmetic. Therefore, there would come a point when people would experience famine and the solution consisted in producing more (soclA AND TWIN, 2015). Concretely, they both differ in various themes.

Thus, according to its methods and objectives, organic agriculture is an alternative system to conventional agriculture, as shown in Table 2. There is a different point of view regarding production, both from the optic of the producer and a different product from the viewpoint of the consumer.

From these types of agriculture $\left(20^{\text {th }}\right.$ century) various facts have taken place, nowadays agricultural activity is mostly implemented intensively, in which the large companies have so much power that they even decide what and how much to produce,

Cuadro 2. Comparación entre métodos y objetivos de la agricultura convencional y la agricultura orgánica. Table 2. Comparison between methods and objectives of conventional agriculture and organic agriculture.

\begin{tabular}{lll}
\hline \multicolumn{1}{c}{ Producción según } & \multicolumn{1}{c}{ Agricultura orgánica } & Agricultura convencional \\
\hline \multirow{2}{*}{ Objetivos } & Producción sostenible & Producción masiva \\
& Consumo local & Consumo dirigido a la exportación \\
\hline & $\begin{array}{l}\text { Trabaja con los ecosistemas de manera integral y respetando } \\
\text { el medio ambiente } \\
\text { Métodos }\end{array}$ & To emplea productos químicos y conserva la fertilidad de nivel de tecnificación \\
& $\begin{array}{l}\text { los suelos } \\
\text { Mantiene la diversidad genética de los cultivos }\end{array}$ & Requiere de alta inversión en capital \\
& Se basa en la utilización óptima de los recursos naturales & Utiliza agro tóxicos y plaguicidas \\
\hline
\end{tabular}

Fuente: elaboración propia con base en: Gómez, 2000; Altieri y Nicholls, 2000; Rendón, 2004; e IfOAM, 2008. Source: authors' elaboration based on: Gómez, 2000; Altieri and Nicholls, 2000; Rendón, 2004; and IFOAM, 2008. 
un punto de vista diferente acerca de la producción tanto desde la óptica del productor y un producto diferente desde el punto de vista del consumidor.

A partir de que estos tipos de agricultura (s. XX) han acontecido diversos hechos, hoy en día la actividad agrícola en su mayoría se lleva a cabo de manera intensiva, en la cual las grandes empresas tienen tanto poder que incluso deciden qué y cuánto producir, dictando entonces el consumo de la población (Escalona, 2009).

Además, estas empresas también deciden cuáles serán los métodos de producción, implementado paquetes tecnológicos que incluyen desde semilla mejorada, uso de fertilizantes químicos, control y manejo de plagas y enfermedades, y en algunas ocasiones el uso de maquinaria, lo cual favorece a los grandes agricultores (Escalona, 2009).

En principio, aunque la tecnología ha incrementado los niveles de producción y la disponibilidad de alimentos por persona, causando beneficios a diversos productores. También ha generado algunas dificultades. Cerca de 1.4 mil millones de personas rurales están fuera de contacto con la agricultura moderna. Casi la totalidad de estas personas son campesinos e indígenas con pequeñas granjas cultivadas en laderas y valles bajo métodos de producción tradicionales. De estas personas, casi 370 millones son extremadamente pobres (afectando mayormente a ancianos, niños y mujeres). Para el caso de México, Colombia, Guatemala y Los Andes, aproximadamente de 19 a 37 millones de personas están propensas a un medio ambiente marginal (Altieri, 2008).

La especialización ha dirigido a la agricultura convencional hacia el monocultivo, que actualmente ocupa $90 \%$ de los 1.5 mil millones de hectáreas destinadas a esta actividad. Cabe destacar que el monocultivo es altamente dependiente de insumos externos y energía; por lo tanto, impacta negativamente en el medio ambiente. Origina erosión, pérdida de fertilidad del suelo, agotamiento de las reservas de nutrientes, salinización, alcalinización y polución de los sistemas de agua. Pérdida de agro biodiversidad y recursos genéticos, eliminación de enemigos naturales, reaparición de plagas, resistencia genética a los plaguicidas, y destrucción de los mecanismos de control naturales (SOCLA y TWIN 2015; Altieri y Nicholls, 2000; Zayas et al., 2012; Gómez, 2000).

En respuesta a estos hechos han surgido diversas iniciativas. A través del diseño de agro ecosistemas dictating then the consumption of the population (Escalona, 2009).

In addition, these companies also decide which will be the production methods, implementing technological packages that include improved seed, use of chemical fertilizers, control and management of pests and diseases, and sometimes the use of machinery, favoring large-scale farmers (Escalona, 2009).

In principle, although technology has increased the levels of production and the availability of foods per person, causing benefits to various producers, it has also generated difficulties. Close to 1.4 billion rural people are out of contact with modern agriculture. Almost all these people are peasants and indigenous people with small farms cultivated on slopes and valleys under traditional production methods. Of these people, nearly 370 million are extremely poor (affecting mostly the elderly, children and women). For the case of Mexico, Colombia, Guatemala and the Andes, approximately 19 to 37 million people are prone to a marginal environment (Altieri, 2008).

Specialization has led conventional agriculture towards monoculture, which currently occupies $90 \%$ of the 1.5 billion hectares destined to this activity. It should be highlighted that monoculture is highly dependent on external inputs and energy; therefore, it impacts the environment negatively. It originates erosion, loss of soil fertility, exhaustion of the nutrient reserves, salinization, alkalinizing and pollution of water systems; loss of biodiversity and genetic resources, elimination of natural enemies, reappearance of pests, genetic resistance to pesticides, and destruction of the mechanisms of natural control (SOCLA and TWIN 2015; Altieri and Nicholls, 2000; Zayas et al., 2012; Gómez, 2000).

In response to these facts diverse initiatives have emerged. Through the design of diversified agro ecosystems and the use of technologies of low inputs, these initiatives have demonstrated the possibility of obtaining a balance between the environment and the yields, facilitating the investment of smallscale producers and providing possibilities outside conventional agriculture both to them and to consumers.

Among the alternatives most often resorted to for this, there is organic agriculture, which in addition to having environmental conservation and 
diversificados y el uso de tecnologías de bajos insumos estas iniciativas han demostrado la posibilidad de obtener un balance entre el medio ambiente y los rendimientos, facilitando la inversión de los pequeńos productores y brindando tanto a estos como a los consumidores posibilidades fuera de la agricultura convencional.

Entre las alternativas más recurridas para esto se encuentra la agricultura orgánica la cual, además de tener como objetivos a la conservación del medio ambiente y la regeneración de los recursos naturales, trata de asegurar la autosuficiencia alimentaria, y mejorar la equidad social y la viabilidad económica mediante la producción de alimentos sanos, promoviendo relaciones más justas y una buena calidad de vida para todos los involucrados (Altieri y Nicholls, 2000; IFOAM, 2008). Además, sus procesos tienen como eje central a las personas y se le considera como una alternativa que satisface las necesidades alimenticias y económicas de consumidores y productores, permitiendo mediante el comercio "cara a cara", generando propuestas de integración, convivencia, aprendizaje y de regreso a la colectividad (Escalona, 2009). Por lo tanto, este sistema de producción beneficia y mejora los criterios: ambiental, económico, social y cultural.

Este trabajo pretende mostrar mediante un análisis descriptivo que los tianguis ${ }^{4}$ y mercados ${ }^{5}$ orgánicos (los cuales para el caso de interés son considerados de manera espacial, es decir, como lugares donde se lleva a cabo el intercambio de mercancías, procedentes de la agricultura orgánica) son una alternativa para mejorar la sostenibilidad económica de los pequeños productores que participan en ellos.

\section{Marco Teórico}

Esta sección permite analizar de manera más clara los conceptos más utilizados y bajo los cuales se rige el tema de investigación.

\section{Agricultura orgánica}

En la sección anterior se mencionó la definición sobre lo que se considera que es el sistema de producción agrícola orgánico, el cual para el Departamento de Agricultura de Estados Unidos (USDA) ${ }^{6}$, además de evitar o excluir el uso de fertilizantes, plaguicidas, reguladores de crecimiento y aditivos compuestos sintéticamente, incluye una tecnología de producción the regeneration of natural resources as objectives, attempts to ensure dietary self-sufficiency and to improve social equity and economic viability through the production of healthy foods, promoting fairer relationships and a good quality of life for everyone involved (Altieri and Nicholls, 2000; IFOAM, 2008). In addition, its processes have people as the central axis and it is considered as an alternative that satisfies the dietary and economic needs of consumers and producers, allowing "face to face" commerce, generating proposals for integration, coexistence, learning and a return to collectivity (Escalona, 2009). Therefore, this production system benefits and improves the environmental, economic, social and cultural criteria.

This study attempts to show through a descriptive analysis that the tianguis (street markets) ${ }^{4}$ and organic $^{5}$ markets (which for the case of interest are considered spatially, that is, as places where the exchange of merchandises from organic agriculture takes place) are an alternative to improve the economic sustainability of small-scale producers who participate in them.

\section{Theoretical Framework}

This section allows analyzing more clearly the concepts most frequently used, which govern the theme of this research.

\section{Organic agriculture}

In the previous section the definition about what is considered to be the system of organic agriculture is mentioned, which for the United States Department of Agriculture (USDA) ${ }^{6}$, in addition to avoiding or excluding the use of fertilizers, pesticides, growth regulators and synthetically made additives, includes production technology based on crop rotation; the use of animal manure; the use of legumes, green fertilizers, organic residues (originated outside the property), natural minerals; aspects of biological pest control to maintain the structure and productivity of the soil, contributing nutrients for the plants and controlling insects, weeds and other pests; and mechanical farming, which makes organic agriculture be a development strategy that attempts to change some limitations found in conventional production in addition to a production method, 
apoyada en la rotación de cultivos; la utilización de estiércol de animales; el uso de leguminosas, abonos verdes, residuos orgánicos (originados fuera de predio), minerales naturales; aspectos de control biológico de plagas para mantener la estructura y productividad del suelo, aportar nutrientes para las plantas y controlar insectos, malezas y otras plagas y; cultivo mecánico, lo cual hace que, además de un método de producción, la agricultura orgánica sea una estrategia de desarrollo que trata de cambiar algunas limitaciones encontradas en la producción convencional, puesto que su fundamento no se basa solamente en un mejor manejo del suelo y fomento al uso de insumos locales, sino también en un mayor valor agregado y una cadena de comercialización más justa (Soto, 2003).

\section{Mercado y tianguis}

A lo largo del tiempo el hombre se ha visto en la necesidad de llevar a cabo el intercambio. Aquí se desprende el concepto del mercado, el cual es un modelo económico en donde se tratan de satisfacer ciertas necesidades o deseos. Este modelo cuenta con dos actores, el oferente y el demandante, quienes lograrán el intercambio siempre y cuando ambos lleguen a un acuerdo (Braudel, 1986).

Para llegar al mercado el hombre debe ser: 1) productor de bienes; 2) tener tendencia de trocar, permutar o intercambiar alguna cosa por otra; por lo tanto, es necesario que haya un excedente en la producción; 3) asumir un comportamiento egoísta y actuar de acuerdo con sus intereses; y 4) debe tener la certidumbre de poder intercambiar el excedente de su producción (Smith, 1988).

El origen del mercado verde, ambiental, ecológico, orgánico o sostenible nació en Europa (Coddington, 1993; Fisk, 1973; Fuller, 1999). Surgió debido a la identificación de algunas producciones específicas que se consideraron dañinas para la atmósfera terrestre (Shil, 2012). Desde 1960 las cuestiones ambientales ganaron importancia debido a que los consumidores se familiarizaron con los productos fabricados de manera amistosa con el medio ambiente (Prakash, 2002). Estos ahora son más conscientes de que, además de los beneficios a la salud, el consumo de productos orgánicos ayuda a reducir la huella ecológica, disminuir la distancia que recorre un alimento desde su origen hasta su lugar de consumo (ya que el consumo orgánico es desde lo local), la since its foundation is not based solely on a better management of the soil and promotion of the use of local inputs, but also a higher added value and a fairer commercialization chain (Soto, 2003).

\section{Market and tianguis (street market)}

Throughout time man has found himself in the need to exchange. This is where the market concept derives, which is an economic model where certain needs or desires are attempted to be satisfied. This model has two actors, the offering and demanding parties, who will achieve the exchange provided that they both reach an agreement (Braudel, 1986).

To reach the market, man must: 1) be a producer of goods; 2) have the tendency to trade, swap or exchange something for another; therefore, it is necessary for there to be an excess in production; 3) assume a selfish behavior and act according to his interests; and 4) must have the certainty of being able to exchange the excess of his production (Smith, 1988).

The origin of the green, environmental, ecological, organic or sustainable market was in Europe (Coddington, 1993; Fisk, 1973; Fuller, 1999). It emerged due to the identification of some specific productions that are considered harmful to the terrestrial atmosphere (Shil, 2012). Since 1960 environmental issues gained importance because consumers becamefamiliar with the products fabricated in an environment-friendly manner (Prakash, 2002). They are now more aware that, in addition to the health benefits, consuming organic products helps reduce the ecological footprint, decrease the distance that food travels from its origin to its place of consumption (since organic consumption is local), mitigate the effect of climate change, and it is the contribution of producers to biodiversity conservation, fair trade, sustainability and food security (Kilcher et al., 2011). In addition, consumers take into account the background and political strength of the organic movement; therefore, the awareness of the population and the role of the State promote the production and the consumption of these products (Gómez et al., 2004).

After 1980 the offering parties were pressured to improve the environmental damage generated by the production of the products they offered. Therefore, barriers arose and the producers resorted to strategies to respond correctly to this change (Peattie and Ratnayaka, 1995). 
mitigación del efecto del cambio climático, la contribución de los productores hacia la conservación de la biodiversidad, el comercio justo, la sostenibilidad y la seguridad alimentaria (Kilcher et al., 2011). Además, los consumidores toman en cuenta los antecedentes y la fuerza política del movimiento orgánico; por lo tanto, la conciencia de la población y el papel del Estado fomentan la producción y el consumo de estos productos (Gómez et al., 2004).

Después de 1980 los oferentes fueron presionados para mejorar el daño medio ambiental generado por la producción de los productos que ofrecían. Por lo tanto, surgieron barreras y los productores recurrieron a estrategias para responder correctamente ante este cambio (Peattie y Ratnayaka, 1995).

Esto generó alternativas hacia mercados que integran todas las actividades, como fabricación, gestión y comercialización. La finalidad fue facilitar el intercambio y satisfacer las necesidades o deseos humanos. Las estrategias aplicadas son: de promoción del producto empleando atributos, sistemas, políticas y procesos que, además de aumentar las ventas, hacen que las empresas o vendedores trabajen en cuestiones de ecología industrial, considerando estas cuestiones como una oportunidad de responsabilidad, de desarrollo de negocios y crecimiento empresarial, generando el mínimo impacto negativo en el medio ambiente (Prakash, 2002; Polonsky, 1994; Coddington, 1993).

\section{Sostenibilidad}

La definición de sostenibilidad a gran escala es la capacidad de comportarnos, de tal manera que dejemos en el futuro o para las generaciones futuras la posibilidad de tener el bienestar actual (Solow, 1991). Sin embargo este concepto tiene un carácter multidisciplinario, ya que la sostenibilidad puede ser: económica, ambiental y socio-cultural. Por lo tanto, no hay un objetivo específico sobre lo que se debe heredar a las generaciones futuras.

Para el caso de este trabajo, el enfoque económico de la sostenibilidad es el que más interesa, ya que el objetivo es saber el hecho de llevar a cabo un método de producción alterno al convencional, e integrarse dentro de un tianguis o mercado orgánico puede mejorar la situación económica de los pequeños productores.

Entonces, la sostenibilidad "es un conjunto de patrones económicos a través de los cuales el bienestar intergeneracional no disminuye" (Arrow et al.,
This generated alternatives towards markets that integrate all the activities, such as fabrication, management and commercialization. The aim was to facilitate the exchange and to satisfy human needs or desires. The strategies applied are: promotion of the product using attributes, systems, policies and processes which, in addition to increasing sales, make the companies or sellers work in issues of industrial ecology, considering these matters as an opportunity for responsibility, business development and entrepreneurial growth, generating the minimum negative impact on the environment (Prakash, 2002; Polonsky, 1994; Coddington, 1993).

\section{Sustainability}

The definition of large-scale sustainability is the capability to behave in a way which allows the possibility of having the current well-being, in the future or for future generations (Solow, 1991). However, this concept has a multidisciplinary character, since sustainability may be: economic, environmental and sociocultural. Therefore, there is no specific objective about what should be inherited to future generations.

For the case of this study, the economic approach of sustainability is what is most interesting, since the objective is to understand the fact that implementing a productive method alternative to the conventional, and becoming integrated in a tianguis or organic market, can improve the economic situation of small-scale producers.

Then, sustainability is "a set of economic patterns through which intergenerational welfare does not decrease" (Arrow etal., 2010). Therefore, sustainability must take into account that the companies or people who are devoted to the production of goods or services will consider the conditions of the economy to continue with their productive strategies. This implies that the investment in sustainability will increase when the economy is restrictive, because it will seek the way of doing more with less, which tends to increase the sustainability strategies due to innovation (Barnett et al., 2014).

Now it is necessary to reach a consensus on the definition of sustainability and its relationship to agriculture, as well as the conditions for both to happen. 
2010). Por lo tanto, la sostenibilidad debe tomar en cuenta que las empresas o personas que se dedican a la producción de bienes o servicios considerarán las condiciones de la economía para seguir con sus estrategias productivas. Esto implica que la inversión en la sostenibilidad aumentará cuando la economía sea restrictiva, debido a que buscará la manera de hacer más con menos, lo cual tiende a aumentar las estrategias de sostenibilidad debido a la innovación (Barnett et al., 2014).

Ahora es necesario consensuar una la definición sobre sostenibilidad y su relación con la agricultura así como las condiciones para que ambas se den.

\section{Sostenibilidad y agricultura}

La sostenibilidad debe reducir costos y aumentar la eficiencia y viabilidad económica, promoviendo un sistema agrícola diverso y flexible (Altieri y Nichols, 2000).

La hipótesis es que un sistema será económicamente sostenible si brinda autosuficiencia alimentaria, si genera al grupo familiar un ingreso anual y si disminuye el riesgo en el tiempo (Sarandón et al., 2008).

Un sistema de producción agrícola sostenible permite mantener los bienes y servicios que satisfacen las necesidades económicas, ecológicas y socio-culturales de los individuos a través del tiempo dentro de los límites físicos de los agro-ecosistemas que soportan dichas necesidades. Es decir, que la satisfacción de las necesidades de la población no puede lograrse a expensas de los recursos naturales (Sarandón et al., 2008). Consecuentemente, las condiciones necesarias para llevar a cabo una agricultura sostenible son: 1) que sea suficientemente productiva; 2) económicamente viable; 3) ecológicamente adecuada; y 4) cultural y socialmente aceptable (Sarandón, 2002).

Por lo tanto, la agricultura orgánica sostenible se da cuando provee: autosuficiencia alimentaria, un ingreso suficiente y disminución en el riesgo económico. Cuando conserve o mejore la base de los recursos productivos, evitando o reduciendo el impacto sobre los recursos y cuando se mantenga o mejore el capital social, tanto en su calidad de vida como en su nivel de dependencia, grado de integración social, nivel de conciencia y conocimiento ecológico (Sarandón et al., 2008).

\section{Sustainability and agriculture}

Sustainability must reduce costs and increase the economic efficiency and viability, promoting a diverse and flexible agricultural system (Altieri and Nichols, 2000).

The hypothesis is that a system will be economically sustainable if it provides dietary self-sufficiency, if it generates an annual income for the family group, and if it decreases the risk in time (Sarandón et al., 2008).

A sustainable agricultural production system allows maintaining the goods and services that satisfy the economic, ecological and sociocultural needs of individuals through time within the physical limits of the agro-ecosystems that sustain those needs. That is, that the satisfaction of the needs of the population cannot be achieved at the expense of natural resources (Sarandón et al., 2008). Consequently, the conditions necessary to implement sustainable agriculture are: 1) that it is sufficiently productive; 2) economically viable; 3) ecologically adequate; and 4) culturally and socially acceptable (Sarandón, 2002).

Therefore, sustainable organic agriculture takes place when it provides: dietary self-sufficiency, sufficient income, and a decrease in economic risk. When it conserves or improves the base of productive resources, avoiding or reducing the impact on the resources, and when it maintains or improves social capital, both in their quality of life and in their level of dependency, degree of social integration, level of awareness and ecological knowledge (Sarandón et al., 2008).

\section{Situation of organic agriculture in Mexico}

In Mexico, organic agriculture emerged as a result of influence from foreign countries that began to demand tropical and winter products, produced under an organic system. This request took place through some trading companies, NGOs and religious groups (Liberation Theology) (Gómez et al., 2010). Organic production in Mexico began in areas where the synthesis inputs were not used; such was the case of indigenous regions and traditional agriculture areas in the states of Chiapas and Oaxaca (Gómez et al., 2010).

Later, the consumers took on an important role in the development and establishment of markets directed towards the sale of organic products, 


\section{Situación de la agricultura orgánica en México}

En México la agricultura orgánica surgió como influencia de países extranjeros que comenzaron a demandar productos tropicales y de invierno, producidos bajo un sistema orgánico. Esta solicitud se dio a través de algunas comercializadoras, ONG y grupos religiosos (Teología de la liberación) (Gómez et al., 2010). La producción orgánica en México comenzó en áreas donde los insumos de síntesis no eran empleados, tal era el caso de las regiones indígenas y áreas de agricultura tradicional en los estados de Chiapas y Oaxaca (Gómez et al., 2010).

Posteriormente, los consumidores tomaron un rol importante en el desarrollo y establecimiento de los mercados orientados a la venta de productos orgánicos, reconociendo que a través de su elección pueden generar un efecto positivo tanto en el medio ambiente como en el bienestar de los pequeños productores (Soto, 2003).

Desde su inicio, el crecimiento en la producción orgánica ha tenido gran impacto en México (Gómez et al., 2004). Este crecimiento se concentra en los estados de Chiapas, Oaxaca, Veracruz (estados donde se encuentra alrededor de $70 \%$ de la biodiversidad del país) y Michoacán (Gómez et al., 2010). Esto denota la dimensión particular de la agricultura orgánica en México, ya que su producción está estrechamente ligada con la geografía de la pobreza y la biodiversidad, vinculándose en su mayoría con pequeńos productores caracterizados principalmente como por sus niveles de pobreza y marginación (Gómez et al., 2010). Por lo tanto, una estrategia correcta puede llevar a quienes llevan a cabo esta actividad agrícola a la reducción de su dependencia alimentaria, la generación de empleo rural, la mejora en su ingreso, la reducción de la migración de la pobreza y a la generación de externalidades positivas(Gómez et al., 2010).

Entre 1996 y 2008 su crecimiento anual fue de más de $3 \%$. Como resultado de esto, el empleo formal ha aumentado hasta un $26 \%$ anual. En lo que respecta a las divisas se dio un aumento de $28 \%$ y se han involucrado más de 129000 productores y 400000 hectáreas (Gómez et al., 2010). En términos de la superficie de producción también se ha observado aumento durante la última década, pasando de 23265 hectáreas en 1996 a más de 400000 ha recognizing that through their choice they could generate a positive effect both in the environment and in the welfare of small-scale producers (Soto, 2003).

From its beginning, the growth in organic production has had a large impact in Mexico (Gómez et al., 2004). This growth is centered in the states of Chiapas, Oaxaca, Veracruz (states where around $70 \%$ of the country's biodiversity is found) and Michoacán (Gómez et al., 2010). This denotes the particular dimension of organic agriculture in Mexico, since its production is closely linked to the geography of poverty and biodiversity, connecting mostly with small-scale producers characterized mainly by their levels of poverty and marginalization (Gómez et al., 2010). Therefore, a correct strategy can lead those who carry out this agricultural activity to the reduction of their dietary dependency, the generation of rural employment, the improvement in their income, the reduction of migration from poverty, and the generation of positive externalities (Gómez et al., 2010).

Between 1996 and 2008, its annual growth was more than $3 \%$. As a result of this, formal employment has increased up to $26 \%$ annually. Concerning the currencies, an increase of $28 \%$ took place and more than 129000 producers and 400000 hectares have been involved (Gómez et al., 2010). In terms of the production surface, an increase has also been seen during the last decade, going from 23265 hectares in 1996 to more than 400000 ha in 2005 (De la Cruz et al., 2012, citing Gómez 2005).

In the period of 1996 to 2012, there has been an increase of $17.31 \%$ of the Mean Rate of Annual Growth (Tasa Media de Crecimiento Annual, TMCA) in Mexico, regarding the number of producers who work under the standards of organic production, as shown in Figure 1.

The growth of the organic sector represents an advantage in the struggle to attain a more sustainable dietary system. Therefore, it is necessary to implement institutional plans that allow a broader development, plans and programs that are focused on the internal market, where the small-scale producers are the ones who could obtain comparative advantages (De la Cruz et al., 2012).

It is also important that small-scale producers become organized with the goal of eliminating the exclusion that globalization has generated. In 
en 2005 (De la Cruz et al., 2012, citando a Gómez 2005).

Del periodo de 1996 a 2012 en México se ha dado un aumento de $17.31 \%$ de la Tasa Media de Crecimiento Anual (TMCA) respecto al número de productores que trabajan bajo los estándares de producción orgánica como se muestra en la Figura 1.

El crecimiento del sector orgánico representa un avance en la lucha por lograr un sistema alimentario más sostenible. Por lo tanto, es necesario implementar esquemas institucionales que permitan un desarrollo más amplio, planes y programas que se enfoquen en el mercado interno, donde son los pequeños productores los que podrán obtener ventajas comparativas (De la Cruz et al., 2012).

Es importante también que los pequeños productores se organicen con el fin de eliminar la exclusión que les ha generado la globalización. Para esto sería necesario: 1) ingresar al mercado con productos de alta calidad y en volúmenes adecuados; 2) instrumentar sistemas internos de control que garanticen el cumplimiento de los criterios de producción orgánica; 3) capacitación para resguardar la calidad y lineamientos de la producción; 4) hacer de la producción orgánica una forma de vida, más que un sistema de producción; y 5) formar cuadros técnicos para promover un mayor compromiso entre los productores (Gómez y Gómez, 2004).

Actualmente hay un mayor número de iniciativas de comercialización a través de varios canales, como tiendas especializadas, tiendas naturistas y cafeterías. Sin embargo, la importancia de los tianguis y mercados orgánicos es que tanto en comunidades rurales como urbanas estos ayudan a conectar a las poblaciones del campo y la ciudad, promover el mercado regional, y consumir de manera directa y a un precio justo para productores y consumidores. Además, ayudan a generar conciencia ecológica y social para producir y consumir en forma responsable, promueven los principios de la agricultura orgánica y ofrecen espacios para la convivencia y el aprendizaje (REDAC, 2013). Por lo tanto, se espera que la integración de los pequeños productores a tianguis o mercados orgánicos que forman parte de la REDAC sea creciente y que les ayude a incrementar su producción, mejorar sus niveles de comercialización, y así, a aumentar su sostenibilidad económica.

Esto se debe a que la integración en algún tianguis o mercado permite que el productor adquiera ciertas obligaciones y beneficios. Por ejemplo, el productor

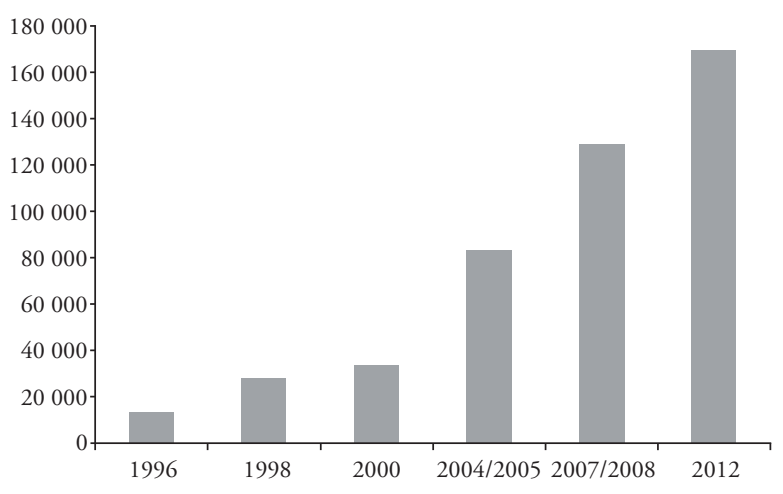

Fuente: elaboración propia con base en información de Gómez et al., 2010. * Source: authors' elaboration based on information by Gómez et al., 2010.

Figura 1. México. Número de productores bajo el sistema de producción orgánica (1996-2012).

Figure 1. Mexico. Number of producers under the organic production system (1996-2012).

order for this, it would be necessary: 1) to enter the market with high-quality products and in adequate volumes; 2) to implement internal systems of control that ensure the compliance of criteria for organic production; 3) to have training to protect the quality and guidelines of production; 4) to make organic production a way of life, rather than a production system; and 5) to create technical panels to promote a greater commitment between producers (Gómez and Gómez, 2004).

Presently there is a higher number of commercialization initiatives through many channels, such as specialized stores, holistic stores and coffee shops. However, the importance of the tianguis and organic markets is that both in rural and urban communities they help to connect the populations from the farmland and the city, to promote the regional market, and to consume directly and at a fair price for producers and consumers. In addition, they help to generate ecological and social awareness to produce and consume responsibly, they promote the principles of organic agriculture and they offer spaces for sharing and learning (REDAC, 2013). Therefore, it is expected that the integration of smallscale producers to tianguis or organic markets that are part of the REDAC will increase and it will help them to increase their production, improve their levels of commercialization, and therefore, to increase their economic sustainability. 
se ve obligado a cumplir con requisitos considerados dentro de la producción orgánica, lo cual origina mayor credibilidad para las personas que adquieren su producto. Además, cuentan con un espacio fijo para comercializar sus productos, facilitando que las personas que visitan semanalmente los tianguis y mercados orgánicos de la red puedan ubicarlo. Por lo tanto, se considera que la relación entre el ingreso de los pequeños productores a los mercados y tianguis que integran a la REDAC sea positiva.

\section{Creación de los primeros tianguis y mercados orgánicos en México}

En México, los primeros tianguis o mercados orgánicos surgieron de manera independiente y en diferentes contextos, pero siempre en áreas urbanas. En sus inicios se establecieron aprovechando la ayuda de instituciones de educación, culturales o municipales. La principal característica de su aparición fue la preocupación sobre el riesgo en la salud, propiciado por las formas de producción, procesamiento y comercialización de los alimentos, aunado al impacto de estos sistemas en el medio ambiente (Escalona, 2009).

El inicio de estos tianguis y mercados se dio en Guadalajara en 1998; la primera propuesta fue establecida como un punto de venta llamado Ecotienda, la cual surgió por la inquietud de diversos ciudadanos por dar seguimiento a las prácticas aprendidas en los talleres de educación ambiental que promovía el Colectivo Ecologista de Jalisco en la década de los ochenta. Posteriormente se vincularon diversos productores constituyendo el Círculo de Producción y Consumo Responsable, transformando a la Ecotienda en un espacio semanal para llevar a cabo el intercambio entre el campo y la ciudad, promoviendo alternativas de producción orgánica local, de comercio justo y consumo responsable, en donde las actividades didácticas, de promoción, difusión y vinculación son fundamentales (García, 2015).

En 2001 se creó la Red de Consumidores de Productos Orgánicos en Chapingo con iniciativa de estudiantes, académicos y consumidores. Para 2003, con la participación de grupos académicos de la Universidad Autónoma Chapingo, consumidores, organizaciones de la sociedad civil, estudiantes y productores, esta idea se transformó en el Tianguis Orgánico Chapingo, cuya intención era llevar a cabo un intercambio material, cultural y de vinculación donde la idea principal fue la venta directa (García, 2015).
This is because the integration into a tianguis or market allows the producer to acquire certain obligations and benefits. For example, the producer is forced to comply with the requirements considered within organic production, which originates higher credibility for people who purchase his product. In addition, they have a fixed space to commercialize their products, making it easy for people who visit the tianguis or organic markets of the network every week to locate them. Therefore, it is considered that the relationship between the income of small-scale producers and the markets and tianguis that make up the REDAC is positive.

\section{Creation of the first tianguis and organic markets in Mexico}

In Mexico, the first tianguis or organic markets emerged independently and in different contexts, although always in urban areas. In their beginning they were established taking advantage of the support by educational, cultural or municipal institutions. The main characteristic of their appearance was the preoccupation about the risk to health, fostered by the forms of production, processing and commercialization of foods, in addition to the impact of these systems on the environment (Escalona, 2009).

The beginning of these tianguis and organic markets took place in Guadalajara in 1998; the first proposal was established as a sales point called Ecotienda, which arose due to the concern of various citizens to continue with the practices learned in the environmental education workshops promoted by Jalisco's Ecological Collective in the decade of the 1980s. Later, various producers connected, establishing the Circle of Responsible Production and Consumption, transforming the Ecotienda into a weekly space to carry out the exchange between farmland and city, promoting local alternatives of organic production, fair trade and responsible consumption, where the activities of teaching, promotion, outreach and market relations are fundamental (García, 2015).

The Network of Consumers of Organic Producers was created in Chapingo in 2001, from the initiative of students, academia and consumers. By 2003, with the participation of academic groups from the Universidad Autónoma Chapingo, consumers, 
La tercera iniciativa se dio por el interés de consumidores y productores preocupados por el medio ambiente, la sanidad y la seguridad alimentaria, quienes organizaron tres ferias orgánicas, contactando a los productores del municipio de Teocelo (Veracruz). De ahí partió la idea de abrir un mercado orgánico permanente y para 2003 se creó el Tianguis Agroecológico de Xalapa. La Universidad Veracruzana apoyó este proyecto y aportó personal académico para su coordinación. La idea principal de este tianguis fue la promoción de productores de áreas rurales cercanas y la venta directa (García, 2015).

Para 2003 surgió el Tianguis Orgánico el Pochote como protesta a la instalación de un McDonald's en el centro histórico de Oaxaca. Este proyecto se llevó a cabo por iniciativa de profesores, artistas y productores invitados (el principal promotor fue el Mtro. Francisco Toledo) (Nelson et al., 2007).

Otra de las iniciativas de tianguis y mercados orgánicos en México es el Mercado Alternativo Tlaxcala. Las reuniones para su creación comenzaron en 2003; sin embargo, el mercado inició actividades en 2005. Su finalidad fue la promoción de la cultura del consumo responsable y la producción agroecológica en sus aspectos sociales, económicos, ambientales y culturales. El desarrollo de este mercado se dio con la participación de Ana Elena Caballero (coordinadora del proyecto), organizaciones como el Proyecto de Desarrollo Integral Vicente Guerrero A.C., Centro Campesino para el Desarrollo Sustentable A.C., Casa de Promoción Social Presentación de Tlaxcala y Herbario de Tlaxcala. Entre otros actores están la Dra. Rita Schwentesius, el Dr. Manuel Ángel Gómez Cruz, y la Mtra. Laura Gómez Tovar, quienes brindaron asesoría en el proceso; el Sr. Santiago Martini, la Sra. Ofelia Cova Juárez y el Dr. Jürgens (con apoyo en principios cooperativos, promoción y procesos productivos, respectivamente) (García, 2015).

Entre las características principales de los mercados está la promoción de una mejor alimentación mediante productos orgánicos y la protección del medio ambiente; sin embargo, todos los tianguis y mercados son entidades independientes y cada uno cuenta con sus propias características (REDAC, 2013; Schwentesius et al., 2013).

Para que estas iniciativas de comercialización funcionen, los productores deben organizarse para solicitar apoyos, acceso a la información y aumentar la civil society organizations, students and producers, this idea transformed into the Chapingo Organic Tianguis, whose intention was to carry out material, cultural and market relations exchange where the main idea was direct sales (García, 2015).

The third initiative took place due to the interest of consumers and producers worried for the environment, safety and food security, who organized three organic fairs, contacting producers from the municipality of Teocelo (Veracruz). The idea of opening a permanent organic market was a result of this, and by 2003 the Xalapa Agroecological Tianguis was created. The Universidad Veracruzana supported this project and contributed academic staff for its coordination. The main idea of this tianguis was the promotion of producers from nearby rural areas and direct sales (García, 2015).

By 2003 the El Pochote Organic Tianguis arose as protest against the installation of a McDonald's in the historical center of Oaxaca. This project was carried out from the initiative of professors, artists, and producers invited (the main promoter was Professor Francisco Toledo) (Nelson et al., 2007).

Another one of the initiatives of tianguis and organic markets in Mexico is the Tlaxcala Alternative Market. The meetings for its creation began in 2003; however, the market began activities in 2005. Its aim was the promotion of a culture of responsible consumption and agroecological production in its social, economic, environmental and cultural aspects. The development of this market took place with the participation of Ana Elena Caballero (coordinator of the project), organizations like Proyecto de Desarrollo Integral Vicente Guerrero A.C., Centro Campesino para el Desarrollo Sustentable A.C., Casa de Promoción Social Presentación de Tlaxcala and Herbario de Tlaxcala. Among other actors, the following: Dr. Rita Schwentesius, Dr. Manuel Ángel Gómez Cruz, and M.Sc. Laura Gómez Tovar, who provided advice in the process; Mr. Santiago Martini, Mrs. Ofelia Cova Juárez and Dr. Jürgens (with support in cooperative principles, promotion and productive processes, respectively) (García, 2015).

Among the main characteristics of the markets there is the promotion of a better diet through organic products, and the protection of the environment; however, all the street and organic markets are independent entities and each one has its own characteristics (REDAC, 2013; Schwentesius et al., 2013). 
credibilidad sobre sus métodos de producción (Gómez et al., 2005).

En el siguiente apartado se hace mención sobre el origen, objetivos, funcionamiento e integración de la Red Mexicana de Tianguis y Mercados Orgánicos, la cual es uno de los actores más importantes de México para el desarrollo de este tipo de agricultura a pequeña y mediana escala.

\section{Red Mexicana de Tianguis y Mercados Orgánicos}

La Red Mexicana de Tianguis y Mercados Orgánicos fue creada en 2004. Fue constituida legalmente en 2008 con el objetivo de acceder a recursos financieros para su desarrollo. Es un grupo de la sociedad civil, integrado por tianguis y mercados orgánicos locales y regionales de pequeños o medianos productores, consumidores y promotores. De 2004 a 2010 la REDAC contó con el apoyo financiero de la Organización No Gubernamental (ONG) Falls Brook Centre de Canadá, esto permitió cubrir gastos de dos a tres reuniones al año, pagando a dos representantes por mercado o tianguis, los gastos de alimentación, alojamiento y traslado, además se cubrieron gastos de promoción y difusión. Durante 2010 y 2011 se consiguió un financiamiento por parte de SAGARPA para apoyar la Certificación Participativa (CP); con esto se organizaron talleres de capacitación respecto a la producción y certificación, así como materiales de divulgación. Cabe destacar que en la actualidad la red no recibe contribuciones económicas directas por parte de los integrantes a los mercados y tianguis (Schwentesius et al., 2013).

Debido a que los tianguis y mercados orgánicos abarcan desde Baja California hasta Chiapas, en 2010 la REDAC se dividió en tres regiones: centro-norte, golfo y sur. (Schwentesius et al., 2013).

Su origen se dio debido a la creciente cantidad de tianguis y mercados orgánicos a lo largo de la república Mexicana, en especial en el centro y sur del país. El surgimiento de estos mercados fue con iniciativa de académicos, consumidores y ONGs, quienes invitaron a productores a venderles una vez por semana sus productos (Schwentesius et al., 2013). La red cuenta con la siguiente estructura organizacional que se muestra en la Figura 2.

Entre los principales objetivos de la red, según su acta constitutiva, se incluye: promover la reconversión de productos convencionales y naturales a
For these initiatives of commercialization to function, producers must be organized to request supports, access to information, and to increase the credibility of their production methods (Gómez et al., 2005).

In the next section, the origin, objectives, functioning and integration of the Mexican Network of Street and Organic Markets (Red Mexicana de Tianguis y Mercados Orgánicos) will be addressed, which is one of the most important actors in Mexico for the development of this type of agriculture at the small and medium scale.

\section{Red Mexicana de Tianguis y Mercados Orgánicos}

The Mexican Network of Street and Organic Markets (Red Mexicana de Tianguis y Mercados Orgánicos REDAC) was created in 2004. It was constituted legally in 2008 with the objective of gaining access to financial resources for its development. It is a civil society group, integrated by street markets and local and regional organic markets of small-scale or medium-scale producers, consumers and promoters. From 2004 to 2010 the REDAC had the financial support of the Falls Brook Centre NGO from Canada; this allowed covering the expenses of two to three meetings per year, paying for two representatives per market or tianguis, food, lodgings and transport expenses; in addition, the expenses for promotion and outreach were also covered. During 2010 and 2011 financing was secured from SAGARPA to support the Participative Certification (Certificación Participativa, CP); with this, training workshops were organized around production and certification, as well as outreach materials. It should be highlighted that currently the network does not receive direct economic contributions from members of the organic and street markets (Schwentesius et al., 2013).

Because the tianguis and organic markets are located from Baja California to Chiapas, in 2010 the REDAC was divided into three regions: centernorth, gulf and south (Schwentesius et al., 2013).

Its origin took place due to the growing number of tianguis and organic markets throughout the Mexican republic, especially in the center and south of the country. The emergence of these markets was from the initiative of academia, consumers and 
orgánicos, y el desarrollo y adaptación de eco-tecnologías alternativas, disminuyendo la dependencia de elementos externos del sistema; asesorar en materia de CP; vincular y promocionar los diferentes tianguis y mercados orgánicos en México, fortaleciendo el comercio local y justo; realizar estudios de diagnóstico de tipo económico, tecnológico y social; participar en eventos académicos, científicos y de divulgación a nivel nacional e internacional; fomentar actividades de formación a través de cursos, talleres, conferencias y otros medios; y celebrar los contratos y ejecutar los actos que sean relativos y conexos con los fines sociales y adquirir los bienes muebles e inmuebles para los establecimientos y servicios de la Asociación, además de participar activamente en el diseño y formulación de políticas públicas relacionadas con la producción local de productos orgánicos (Schwentesius et al., 2013).

La REDAC también tiene como meta específica el mejoramiento de la tierra a través de la agricultura orgánica y los participantes de los mercados que forman parte de la red, tomando en cuenta el concepto de sostenibilidad en el cual incluyen los factores ecológicos, económicos, socio-culturales y de salud (Schwentesius et al., 2013).

Actualmente, la red cuenta con un total de 21 tianguis y mercados orgánicos en 15 estados a lo largo de la República Mexicana.
NGOs, who invited producers to sell their products to them once a week (Schwentesius et al., 2013). The network has the organizational structure shown in Figure 2.

Among the main objectives of the network, according to its bylaws, the following are included: promoting the reconversion of conventional and natural products to organic, and the development and adaptation of alternative eco-technologies, decreasing the dependency on elements outside the system; advising in matters of $\mathrm{CP}$; connecting and promoting the different tianguis and organic markets in Mexico, strengthening the local and fair trade; performing diagnostic studies of economic, technological and social type; participating in academic, scientific and outreach events at the national and international level; promoting training activities through courses, workshops, conferences and other media; and celebrating the contracts and executing the acts that are relative and related to social aims; and acquiring the personal and real estate property for the branches and services of the Association, in addition to participating actively in the design and formulation of public policies related to the local production of organic products (Schwentesius et al., 2013).

The REDAC also has the specific goal of improving the land through organic agriculture and the participants in the markets that are part of the network, taking into account the concept

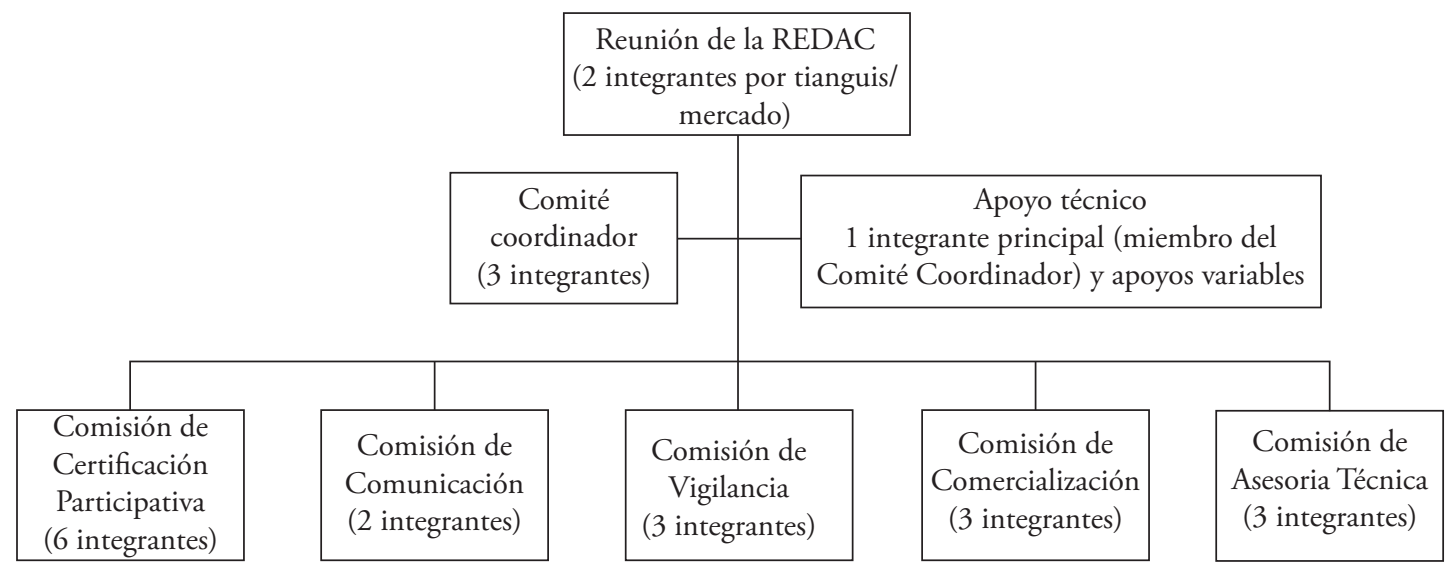

Fuente: elaboración propia con base en información de Schwentesius et al. (2013). \&ource: authors' elaboration based on information by Schwentesius et al. (2013).

Figura 2. Estructura organizacional de la REDAC.

Figure 2. Organizational structure of the REDAC. 


\section{Metodología}

Tal como se planeta en los objetivos, esta investigación busca llevar a cabo una medición de la sostenibilidad de los pequeños productores que se integran a los tianguis y mercados orgánicos de la REDAC en su criterio económico.

Respecto al objetivo de la medición de la sostenibilidad, este se llevó a cabo en tres fases:

- Planeación de la investigación: aquí, se consideró el método y enfoque sobre el cual se dirigiría el estudio, el alcance y diseño de la investigación, y el diseño y prueba de los instrumentos de recolección.

- Levantamiento y captura de la información: incluye la selección de la población objetivo, la aplicación del instrumento de recolección y el diseño de la base de datos y captura de la información.

- Análisis univariado: el análisis descriptivo, gráfico y de correlaciones que ayudarán a describir la situación de los productores que integran a los tianguis y mercados orgánicos de la REDAC en ámbitos como: datos generales del productor; producción, costos, ingresos y ganancias; comercialización y; certificación orgánica. Además, esta fase contempla los indicadores que ayudarán a la medición de la sostenibilidad.

\section{Planeación de la InVestigación}

\section{Método y enfoque de la investigación}

Siempre que se trata del concepto de sostenibilidad se debe llevar a cabo un enfoque multicriterio y el establecimiento de escalas ordinales de medición y métodos de análisis univariado (Rendón, 2004). Esta investigación no es la excepción, puesto que considera el criterio económico, ecológico y socio-cultural en la medición de la sostenibilidad de los pequeños productores, y lleva a cabo escalas que indican el grado de importancia que tienen ciertos factores para la producción, para los productores, etcétera. Además, estas escalas ayudan a clasificar el grado de sostenibilidad de ciertos indicadores. Respecto al análisis univariado se llevan a cabo distribuciones de frecuencia mediante gráficos, medidas de tendencia central y algunas medidas de dispersión. of sustainability in which they include ecological, economic, sociocultural, and health factors (Schwentesius et al., 2013).

Currently, the network has a total of 21 tianguis and organic markets in 15 states throughout the Mexican Republic.

\section{Methodology}

As is suggested in the objectives, this research seeks to carry out a measure of sustainability among small-scale producers that make up the tianguis and organic markets from the REDAC in their economic criterion.

Concerning the objective of measuring sustainability, this was done in three phases:

- Planning the study: here, the method and approach which would direct the study was considered, as well as the reach and design of the study, and the design and trial of the collection instruments.

- Gathering and capturing information: includes the selection of the target population, the application of the collection instrument and the design of the database and information capture.

- Univariate analysis: the descriptive, graphic and correlation analysis that will help to describe the situation of the producers who make up the tianguis and organic markets of the REDAC in spheres such as: general data of the producer; production, costs, income and earnings; commercialization; and, organic certification. In addition, this phase contemplates the indicators that will help to measure the sustainability.

\section{Planning the Research}

\section{Method and approach of the study}

Any time the concept of sustainability is approached, a multi-criteria approach and the establishment ordinal measurement scales and univariate analysis methods must be carried out (Rendón, 2004). This study is not the exception, since it considers the economic, ecological and sociocultural criteria in measuring the sustainability of small-scale producers, and it uses scales that indicate the degree of importance of certain factors 


\section{Alcance y diseńo de la investigación}

Es un estudio transversal no experimental, puesto que las variables no fueron manipuladas y la recolección de datos se dio en un momento único en el tiempo. La investigación tiene tres alcances; el primero es que es un estudio descriptivo, puesto que muestra las características y circunstancias de los pequeños productores del sector orgánico que han decidido integrarse a los tianguis o mercados orgánicos de la REDAC. Además, es un estudio de alcance correlacional, ya que asocia variables que en este caso son los productores hacia un patrón, que es la integración a tianguis/mercados orgánicos y para un grupo poblacional que son los pequeños productores de los mercados que integran a la REDAC. Asimismo, es un estudio de alcance explicativo puesto que establece causas, las cuales para este caso son que la integración de los productores a estos mercados les brinde sostenibilidad en el aspecto económico, ecológico y socio-cultural.

\section{Instrumento de recolección}

La información se recolectó con fuentes primarias obtenidas mediante la aplicación de encuestas a los actores que participan en el sector orgánico a nivel local, es decir, produciendo y comercializando a pequeña escala y dentro de sus localidades. Por lo tanto, la población objetivo se dividió en dos grupos: 1) los productores que forman parte de los tianguis o mercados orgánicos pertenecientes a la REDAC; y 2) los coordinadores de dichos tianguis/ mercados.

Se elaboraron dos cuestionarios, uno estructurado y dirigido a los productores y un cuestionario semi-estructurado para los coordinadores. Ambos se aplicaron a una pequeña muestra en forma de cuestionarios piloto, con el fin de probar su pertinencia y eficacia tanto en cuestiones de aplicación como en resultados. Posteriormente se corrigieron errores y se modificaron algunas opciones de respuesta para así obtener el instrumento definitivo.

Los cuestionarios se aplicaron personalmente y antes de iniciar con las respuestas se mencionó a los productores que las respuestas eran para fines académicos y los datos personales anónimos.

Para el caso de productores el cuestionario incluyó 58 preguntas divididas en cuatro secciones: for production, producers, etc. In addition, these scales help classify the degree of sustainability of certain indicators. Regarding univariate analysis, frequency distributions are done through graphs, central tendency measures, and some dispersion measures.

\section{Reach and design of the study}

It is a non-experimental transversal study, for the variables were not manipulated and data collection took place in a single moment in time. The research has three reaches; the first is that it is a descriptive study, since it shows the characteristics and circumstances of small-scale producers of the organic sector that have decided to join the tianguis or organic markets of the REDAC. In addition it is a study of correlational reach, since it associates variables which in this case are producers towards a pattern, which is the integration to tianguis or organic markets and for a population group which are the small-scale producers of the markets that make up the REDAC. Likewise, it is a study of explicative reach because it establishes causes, which for this case are that the integration of producers to these markets provides them sustainability in the economic, ecological and sociocultural aspect.

\section{Collection instrument}

The information was collected with primary sources obtained through the application of surveys to actors who participate in the organic sector at the local level; that is, producing and trading at a small scale and inside their localities. Therefore, the target population was divided into two groups: 1 ) producers who are part of the street or organic markets belonging to the REDAC; and 2) coordinators of these tianguis and markets.

Two questionnaires were elaborated, one structured and directed at producers and one semistructured questionnaire for the coordinators. They were both applied to a small sample as pilot questionnaires, with the aim of testing their pertinence and efficacy both in matters of application and in results. Then, errors were corrected and some response options were modified to then obtain the definitive instrument.

The questionnaires were applied personally and before beginning with the responses, it was 
a) identificación de los productores; b) producción y comercialización; c) certificación; y d) producción orgánica. Además, se consideró la perspectiva sobre sostenibilidad económica, ecológica y socio-cultural que los productores obtienen al participar en los tianguis o mercados orgánicos.

A los coordinadores se les aplicó una entrevista semiestructurada que incluyó 32 preguntas sobre la constitución, iniciativa, funcionamiento, ubicación, organización e integración para determinar la situación del tianguis o mercado dentro de un contexto descriptivo.

\section{Unidad de análisis}

La REDAC cuenta con 21 tianguis y mercados orgánicos en 15 estados a lo largo de la República Mexicana. Sin embargo, debido a la amplitud del terreno, el tiempo y la estimación de los recursos necesarios para llevar a cabo la aplicación de los cuestionarios se optó por seleccionar tianguis y mercados cercanos con algunas similitudes y facilidades en cuanto al acceso a la información.

Entonces, se seleccionaron los siguientes ocho tianguis y mercados orgánicos.

\section{LeVantamiento y Captura DE LA INFORMACIÓN}

\section{Selección de la población objetivo y tamańo de la muestra}

La población objetivo son los productores y coordinadores de los tianguis y mercados orgánicos de la Figura 3. Se llevó a cabo la aplicación del cuestionario a la mayor cantidad de productores que se encontraban en los tianguis y mercados al momento de llevar a cabo la visita y, respecto a los coordinadores, se entrevistó a ocho, uno en cada tianguis (sin embargo, hay tianguis en los que hay más de un coordinador).

\section{Aplicación del instrumento de recolección}

Los datos se recolectaron en diversos momentos entre agosto 2014 y diciembre de 2015. Se visitaron ocho estados dentro de la República Mexicana: Estado de México, Oaxaca, Puebla, Tlaxcala y Veracruz, aplicando un total de 69 cuestionarios a productores mentioned to producers that their responses were for academic aims and the personal data anonymous.

For the case of the producers, the questionnaire included 58 questions divided in four sections: a) identification of producers; b) production and commercialization; c) certification; and d) organic production. In addition, the perspective about the economic, ecological and sociocultural sustainability obtained by producers when participating in tianguis or organic markets was considered.

A semi-structured interview was applied to the coordinators, which included 32 questions about the constitution, initiative, functioning, location, organization and integration to define the situation of the tianguis or organic market within a descriptive context.

\section{Unit of analysis}

The REDAC has 21 tianguis and organic markets in 15 states throughout the Mexican Republic. However, due to the size of the terrain, the time and the estimation of the resources necessary to carry out the application of the questionnaires, it was decided to select nearby tianguis and markets with some similarities and ease in terms of access to information.

Therefore, the following eight tianguis and organic markets were selected.

\section{GATHERING AND CAPTURING INFORMATION}

\section{Selection of the target population and size of the sample}

The target population is producers and coordinators of the street and organic markets shown in Figure 3. Application of the questionnaire was carried out with the highest number of producers found in the tianguis and markets at the moment of performing the visit and, regarding the coordinators, eight were interviewed, one in each tianguis (however, there are tianguis where there is more than one coordinator).

\section{Application of the collection instrument}

The data were collected in diverse moments between August 2014 and December 2015. Eight states were visited in the Mexican Republic: Estado 


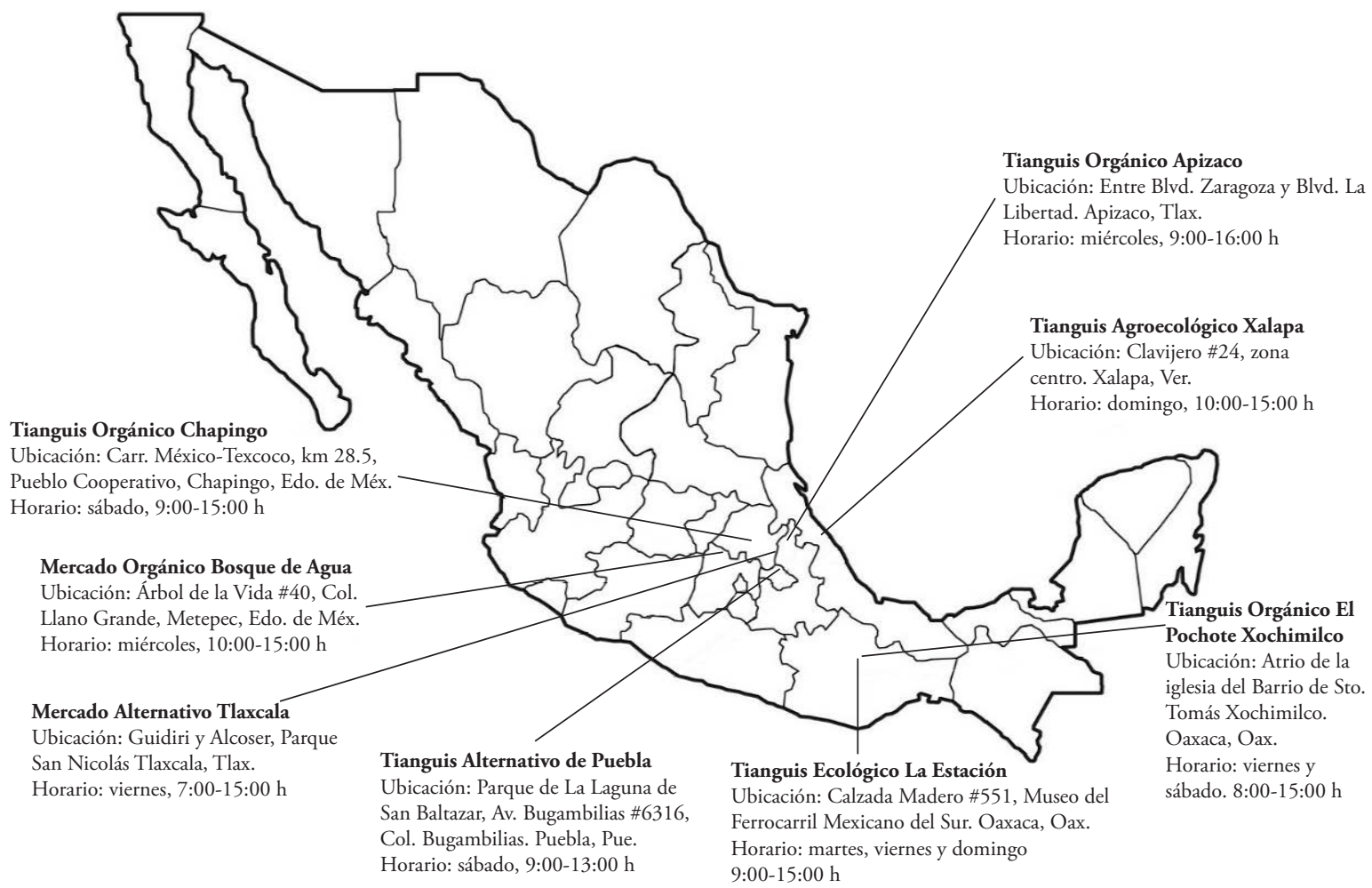

Fuente: elaboración propia. Source: authors' elaboration.

Figura 3. Tianguis y mercados orgánicos encuestados (ubicación y horario).

Figure 3. Tianguis and organic markets surveyed (location and schedule).

y ocho entrevistas semiestructuradas a coordinadores como se muestra en el Cuadro 3.

\section{Diseño de la base de datos y captura de la información}

La encuesta se capturó en la aplicación de Google drive, la cual es una herramienta para almacenar, procesar y compartir documentos. Posteriormente, la información obtenida se exportó a una base de datos diseñada en el programa Excel, de Microsoft Office para llevar cabo la correlación y análisis de los datos.

\section{Análisis de la información}

La tercera fase trata sobre el análisis univariado de la información que se obtuvo mediante la aplicación de las encuestas. Sin embargo, esta se muestra en el siguiente capítulo a manera de resultados puesto que la manera en que se desarrolló es principalmente descriptivo, gráfico y de correlaciones en ámbitos como: datos generales del productor; producción, costos, de México, Oaxaca, Puebla, Tlaxcala and Veracruz, applying a total of 69 questionnaires to producers and eight semi-structured interviews to coordinators as shown in Table 3.

\section{Database design and information capture}

The survey was captured in the Google Drive application, which is a tool to store, process and share documents. Later, the information obtained was exported to a database designed in the Microsoft Office Excel software, to carry out the correlation and analysis of the data.

\section{Information analysis}

The third phase is about the univariate analysis of the information that was obtained through the survey application. However, this is shown in the next section as results because the way in which it was developed is primarily descriptive, graphic and of correlations in spheres such as: producer's general 
Cuadro 3. Tianguis y mercados orgánicos encuestados, número de productores y fecha de visita.

Table 3. Tianguis and organic markets surveyed, number of producers, and date of visit.

\begin{tabular}{lccl}
\hline \multicolumn{1}{c}{ Tianguis o mercado } & Productores & \% de encuestas & Fecha de visita \\
\hline Mercado Agroecológico Xalapa & 11 & 16 & 3 de agosto de 2014 \\
Mercado Alternativo Tlaxcala & 6 & 9 & 8 de agosto de 2014 \\
Tianguis Orgánico Apizaco & 5 & 7 & 5 de noviembre 2014 \\
Tianguis Alternativo de Puebla & 10 & 15 & 8 de noviembre de 2014 \\
Bosque de Agua & 6 & 9 & 12 de noviembre de 2014 \\
Tianguis Orgánico Chapingo & 14 & 20 & 29 de noviembre de 2014 \\
\hline Total & 52 & 100 & - \\
\hline
\end{tabular}

Fuente: elaboración propia con base en las encuestas aplicadas de agosto 2014 a noviembre 2015. \&ource: authors' elaboration based on surveys applied from August 2014 to November 2015.

ingresos y ganancias; comercialización; certificación orgánica. Esta fase también incluye la evaluación de la sostenibilidad que se muestra a continuación.

\section{Perfil y situación de los pequeños productores de los tianguis y mercados orgánicos de la REDAC}

Se aplicaron en total, 52 cuestionarios y la información obtenida al respecto fue la siguiente.

\section{Identificación del productor}

El promedio de edad de las personas que participan en los tianguis y mercados orgánicos es de 44 años; $58 \%$ de los encuestados son hombres y $42 \%$ mujeres; $50 \%$ son casados y $71 \%$ mencionaron que tienen hijos. Solamente $13 \%$ pertenece a algún grupo étnico; $85 \%$ cuenta con hogar propio y el resto pagan una renta mensual que va desde 1,500 pesos (mínimo) y 4200 pesos (máximo).

En cuanto a la escolaridad, $52 \%$ tiene estudios universitarios; $17 \%$, secundaria; $13 \%$, posgrado; $6 \%$, preparatoria; $12 \%$, primaria (no en todos los casos concluida).

\section{Producción y comercialización}

El $84 \%$ se dedica a la producción y comercialización de productos orgánicos. Del total de personas encuestadas, 31 indicaron que ingresaron al tianguis o mercado mediante una solicitud en la cual describían sus productos, métodos de producción y proveedores (en caso de contar con ellos); posteriormente se llevó a cabo una visita al área de producción y la entrega de un dictamen. Seis personas indicaron que data; production, costs, income and earnings; commercialization; organic certification. This phase also includes the evaluation of sustainability that is shown next.

\section{Profile and situation of small-scale producers from REDAC tianguis and organic markets}

In total, 52 questionnaires were applied and the information obtained in this regard was the following.

\section{Identification of the producer}

The average age of the people who participated in the tianguis and organic markets is 44 years; $58 \%$ of the survey respondents are men and $42 \%$ are women; $50 \%$ are married and $71 \%$ mentioned they have children. Only $13 \%$ belongs to an ethnic group; $85 \%$ owns a house and the rest pay a monthly rent that goes from $\$ 1,500$ pesos (minimum) to $\$ 4200$ pesos (maximum).

Regarding schooling, $52 \%$ has university studies, $17 \%$ secondary, $13 \%$ graduate studies, $6 \%$ high school, $12 \%$ primary school (not finished in all cases).

\section{Production and commercialization}

Of producers, $84 \%$ are devoted to the production and commercialization of organic products. Of the total of people surveyed, 31 indicated that they entered the tianguis or market through a request where they described their products, production methods and suppliers (in case of having them); later, 
su ingreso al tianguis fue por invitación por parte del tianguis. Dos personas indicaron que su ingreso al tianguis o mercado fue mediante alguna asociación y el resto no especificaron como fue su ingreso al tianguis.

El $48 \%$ recibe asesoría técnica por parte de su propio tianguis $(13 \%)$ y $37 \%$ por otro medio. La gente comentó que la asesoría técnica les ha enseñado nuevos métodos de producción y prevención de plagas, les ayuda a mejorar la organización, mejorar el proceso productivo, mejorar la nutrición de la tierra, disminuir los costos de producción y reducción de pérdidas.

El $87 \%$ vende sus productos en algún otro lugar; de este porcentaje, $48 \%$ vende en otros tianguis o mercados orgánicos, $13 \%$ en su localidad, $6 \%$ en mercados o tiendas convencionales; $6 \%$ en ferias, expos y bazares, y el resto (37) en otros lugares. Las razones que mencionaron los productores del porque decidieron vender sus productos en otros lugares son:

- Para aumentar los canales de comercialización, por el tipo de lugares en que vende (que son orgánicos o naturales),

- Para aumentar su margen de ganancia,

- Para que la gente conozca sus productos,

- Para no mermar su producción,

- Para ampliar el concepto de lo orgánico

- Por la vinculación directa con los mercados en que trabaja,

- Por demanda de la gente

- Porque busca compartir sus productos a más personas.

Solamente $19 \%$ pertenece a algún grupo organizado de productores orgánicos, los grupos mencionados fueron:

- Coatepec A. C.

- Texcotli A.C.

- Sociedad Mexicana de la Producción Orgánica

- SOMEXPRO

- Asociación de Productores de Tuna Orgánica del Valle de Teotihuacán

- Grupo Vicente Guerrero

- Asociación Centro Campesino para el Desarrollo Sustentable A.C.

- Comité de Sistemas de Producción Apícola del Estado de México. a visit was performed to the production area and there was a decision made. Six people indicated that their entry to the tianguis was by invitation from the street market. Two people indicated that their entry to the tianguis or market was through some association and the rest didn't specify how they entered the street market.

Of them, $48 \%$ receives technical assistance from their own tianguis (13\%) and $37 \%$ through another means. The people mentioned that technical advice has taught them new production methods and pest prevention, it helps them to improve the organization, improve the productive process, improve soil nutrition, decrease the production costs, and reduce losses.

Of them, $87 \%$ sells their products in another place; $48 \%$ of this percentage sells in other tianguis or organic markets, $13 \%$ in their locality, $6 \%$ in markets or conventional stores, $6 \%$ in fairs, expos and bazaars, and the rest (37) in other places. The reasons that the producers mentioned as to why they decided to sell their products in other places are:

- To increase the commercialization channels, because of the type of places where they sell (which are organic or natural),

- To increase their margin of profit,

- For people to get to know their products,

- To avoid reducing their production,

- To broaden the concept of organic,

- For the direct link to the markets where they work,

- Due to demand from people,

- Because they seek to share their products with more people.

Only $19 \%$ belongs to some organized group of organic producers; the groups mentioned were:

- Coatepec A. C.

- Texcotli A.C.

- Sociedad Mexicana de la Producción Orgánica

- SOMEXPRO

- Asociación de Productores de Tuna Orgánica del Valle de Teotihuacán

- Grupo Vicente Guerrero

- Asociación Centro Campesino para el Desarrollo Sustentable A.C.

- Comité de Sistemas de Producción Apícola del 
- Asociación de apicultores de Tlalmanalco Estado de México

- Sociedad de Productores Rurales de la Zona Oriente del Estado de México

- Asociación de Apicultores Alchichica, Puebla

- Asociación de Apicultores de Perote, Veracruz

- Centro de Recolección. Distribución y Venta de Productos Orgánicos Vida Verde

- Productores Orgánicos de Xochimilco A.C.

- Productores Agrícolas de montaña;

- UNORCA

- GREENPACE (Puebla)

Decidieron unirse porque pertenecer a alguna de estas organizaciones ayuda a promover la producción orgánica, genera aprendizaje, credibilidad, y hay una mayor comunicación entre el gobierno y los productores. Además, hay mayor participación en eventos de promoción de los productos orgánicos y se puede obtener recursos.

El promedio de horas trabajadas por semana es de 26.22; quien más horas dedica a la producción orgánica trabaja 70 horas y el dato menor fue de dos horas (tres personas no contestaron).

El $79 \%$ cuenta con personas que le ayudan a producir o cosechar. El promedio de personas empleadas es de 2.92 por productor; sin embargo, el mayor número de empleados por productor es de 10 , mientras que 10 personas no emplean a nadie. De estas personas, $54 \%$ son familiares y el promedio de horas que le ayudan a trabajar es de 7.38 horas; a quien más le ayudan reportó 70 horas por trabajador, pero las horas trabajadas dependen de la época del año y el cultivo. El $48 \%$ de los productores reportó que paga a sus empleados entre 0 a 500 pesos semanales; $21 \%$, de 501 a 1000 pesos; y $8 \%$ de 1501 a 2000 pesos.

\section{Certificación orgánica}

El $69 \%$ de los encuestados cuentan con algún tipo de certificación orgánica; $7 \%$ no y $17 \%$ está en proceso de certificación (generalmente es certificación participativa; solo una persona mencionó que contaba con ambas, participativa y por agencia, la agencia utilizada es CERTIMEX).

De las 52 personas encuestadas, tres no respondieron, mientras que 13 mencionaron que no les cuesta nada; el promedio que pagan las 36 personas restantes por su certificación (anual) es de \$387.77.
Estado de México.

- Asociación de apicultores de Tlalmanalco Estado de México

- Sociedad de Productores Rurales de la Zona Oriente del Estado de México

- Asociación de Apicultores Alchichica, Puebla

- Asociación de Apicultores de Perote, Veracruz

- Centro de Recolección. Distribución y Venta de Productos Orgánicos Vida Verde

- Productores Orgánicos de Xochimilco A.C.

- Productores Agrícolas de montaña

- UNORCA

- GREENPACE (Puebla)

They decided to join because belonging to one of these organizations helps promote organic production, generates learning, credibility, and there is better communication between the government and the producers. In addition, there is greater participation in events promoting organic products and resources can be obtained.

The average hours worked per week is 26.22; those who devote most hours to organic production work 70 hours and those who devote less, two hours (three people did not reply).

Of them, $79 \%$ have people who help them to produce or harvest. The average number of people employed is 2.92 per producer; however, the highest number of employees per producer is 10 , while there are 10 people who do not employ anyone. Of these people, $54 \%$ are family members and the average hours they help to work is 7.38 hours; those who get helped most reported 70 hours per worker, but the hours worked depend on the time of the year and the crop. Of the producers, $48 \%$ reported that they pay employees from 0 to 500 pesos weekly; $21 \%, 501$ to 1000 pesos; and $8 \%, 1501$ to 2000 pesos.

\section{Organic certification}

Of the survey respondents, $69 \%$ have some type of organic certification; $7 \%$ do not and $17 \%$ are in process of certification (generally it is participative certification; only one person mentioned that he had both, participative and by agency, the agency used is CERTIMEX).

Of the 52 people surveyed, three did not respond, while 13 mentioned that it doesn't cost them anything; the average that the 36 remaining 
El $81 \%$ mencionó que tener la certificación orgánica influye de manera positiva en la venta de sus productos y $73 \%$ indicó que el uso de un sello también sería benéfico para el aumento de sus ventas puesto que genera mayor confianza en el consumidor.

En cuanto a sus ingresos semanales, los productores reportaron lo siguiente:

El $58 \%$ menciona que percibe ingreso por actividades externas a la producción orgánica (Cuadro 4).

La mayoría de los productores consideran que la producción orgánica es rentable; mencionan que además del aumento que obtienen en sus ingresos ellos mismos se abastecen y consumen de forma más sana. Venden todo lo que producen, su producción no requiere de muchos costos y la gente busca los productos orgánicos, ya que estos son de mayor calidad y más sanos. Sin embargo, no todos los productores consideran que este sistema de producción es rentable. Una de las principales causas de esto es la falta mercado.

El $81 \%$ considera que el pago que reciben por la venta de sus productos es justo puesto que son ellos quienes ponen el precio, venden calidad y la gente paga por ello; además, el producto va directamente al consumidor, lo cual les permite recuperar los costos de la producción, ya que no hay intermediarios. La inversión es poca, hacen lo que les gusta y, a su vez, generan ganancias.

\section{Conclusiones}

Se ha dado un crecimiento tanto del sector orgánico como de los tianguis y mercados orgánicos. También hay un mayor número de productores que participan en este sistema de producción y con ello aumentan su sostenibilidad económica y ayudan a mejorar el medo ambiente.

La producción orgánica es sin duda un sistema que favorece a los pequeños productores. En principio, people pay for their (annual) certification is $\$ 387.77$. Of them, $81 \%$ mentioned that having the organic certification influences positively the sale of their products and $73 \%$ indicated that the use of a seal would also be beneficial to increase their sales since it generates greater trust in the consumer.

In terms of their weekly income, producers reported the following:

Of them, $58 \%$ mentions they receive income from activities other than organic production.

Most of the producers consider that organic production is profitable; they mention that in addition to the increase they obtain in income, they also supply themselves and consume in a healthier manner. They sell all they produce, their production does not require many expenses and people seek organic products, since they are of higher quality and healthier. However, not all the producers consider that this production system is profitable. One of the main causes of this is the lack of market.

Of producers, $81 \%$ consider that the payment they receive over the sale of their products is just since it is they who set the price, sell quality and people pay for it; in addition, the product goes straight to the consumer, which allows them to recover the production costs, since there are no intermediaries. The investment is low, they do what they like and, at the same time, they generate profits.

\section{Conclusions}

Growth has taken place both in the organic sector and in the tianguis and organic markets. There are also a higher number of producers who participate in this production system and with this they increase their economic sustainability and help to improve the environment.

Cuadro 4. Distribución semanal del ingreso por la venta de productos orgánicos.

Table 4. Weekly distribution of the income over the sale of organic products.

\begin{tabular}{lcccrr}
\hline $\begin{array}{c}\text { Rango de ingreso } \\
\text { semanal }\end{array}$ & $\begin{array}{c}\text { Número de } \\
\text { productores } \\
\text { dentro del rango }\end{array}$ & $\begin{array}{c}\text { \% de productores } \\
\text { dentro del rango }\end{array}$ & $\begin{array}{c}\text { Rango de ingreso } \\
\text { semanal }\end{array}$ & $\begin{array}{c}\text { Número de } \\
\text { productores } \\
\text { dentro del rango }\end{array}$ & $\begin{array}{r}\% \text { de productores } \\
\text { dentro del rango }\end{array}$ \\
\hline 0 a 500 pesos & 13 & $25 \%$ & 1501 a 2000 pesos & 10 & $19 \%$ \\
501 a 1000 pesos & 10 & $19 \%$ & 2001 a 2500 pesos & 4 & $8 \%$ \\
1001 a 1500 pesos & 5 & $10 \%$ & 2501 pesos en adelante & 10 & $19 \%$ \\
\hline
\end{tabular}

Fuente: elaboración propia con base en resultado de encuestas aplicadas en 2014. Source: authors' elaboration based on the result of surveys applied in 2014 . 
los ayuda a satisfacer su consumo de manera autónoma, lo cual reduce sus gastos y les permite tener una mejor alimentación. Además, gran parte de los productores considera que el hecho de participar en algún tianguis o mercado orgánico les da mayor credibilidad sobre el producto que venden puesto que para poder formar parte de alguno de estos medios de comercialización es necesario llevar a cabo la certificación de sus productos, que si bien se hace dentro del mercado les otorga la garantía de ofrecer un producto orgánico.

Sin embargo, es necesario crear propuestas para la acción de políticas agrícolas y ecológico/económicas que relacionen los aspectos de importancia para los pequeńos productores. También es necesario el incremento interno del consumo de productos orgánicos, desarrollar estrategias de promoción que hagan que la gente se concientice sobre los beneficios de la agricultura orgánica y el consumo local.

Por parte de los productores y para el desarrollo de los mercados orgánicos debe existir el registro de datos sobre producción, ventas consumo y precios de productos orgánicos, con el fin de generar transparencia y confianza (Källander y Rundgren, 2009).

Como menciona Altieri y Nicholls (2000), a nivel institucional el sector público se debe asegurar de que los pobres no sean excluidos de los beneficios del desarrollo agrícola; la equidad debe llegar a las comunidades rurales mediante oportunidades reales para que estas puedan protagonizar y solucionar sus problemas sin que los agricultores pierdan su autonomía, organización, cultura y recursos naturales.

\section{Notas}

${ }^{3}$ http://www.ifoam.org/en/organic-landmarks/definition-organic-agriculture

${ }^{4}$ Tianguis: es un espacio donde se lleva a cabo el intercambio de mercancías, en un espacio abierto. * Tianguis: it is a space where the exchange of merchandise takes place, in an open area.

${ }^{5}$ Mercado, es un sitio cerrado con diversos puestos establecidos de manera fija. Market: it is a closed place with various established fixed spots.

${ }^{6}$ http://www.ams.usda.gov/AMSv1.0/nop

\section{Literatura Citada}

Altieri, M. 2008. Agroecology: environmentally sound and socially just alternatives to the industrial farming model.
Organic production is doubtless a system that favors small-scale producers. In principle, it helps them to satisfy their consumption autonomously, reducing their expenses and allowing them a better diet. Also, a large part of producers consider the fact that participating in some tianguis or organic market gives them more credibility over the product they sell, because in order to become part of one of these means of commercialization it is necessary to carry out the certification of their products, which although it is done inside the market it gives them the guarantee of offering an organic product.

However, it is necessary to create proposals for the action of agricultural and ecological/ economic policies that connect important aspects for small-scale producers. The internal increase of consumption of organic products is also necessary, as well as developing promotion strategies that help people become aware about the benefits of organic agriculture and local consumption.

From producers and for the development of organic markets there should be a record of data about production, consumption sales, and prices of organic products, with the aim of generating transparency and trust (Källander and Rundgren, 2009).

As Altieri and Nicholls (2000) mention, at the institutional level the public sector must ensure that the poor are not excluded from the benefits of agricultural development; equity must reach the rural communities through real opportunities for them to become protagonists and solve their problems without farmers losing their autonomy, organization, culture and natural resources.

\section{- End of the English version -}

University of California Berkeley. Revisado 14 de agosto de 2014. www.agroeco.org/publications 2 p.

Altieri, M., y Nicholls C. 2000. Agroecología: Teoría y práctica para una agricultura sustentable. 1ra edición, Serie Textos Básicos para la Formación Ambiental, Programa de las Naciones Unidas para el Medio Ambiente (PNUD), Red de Formación Ambiental para América Latina y El Caribe, México D.F.

Arrow K. J., Dasgupta P., Lawrence H. G., Mumford K. J., y Oleson K. 2010. Sustainability and the measurement of wealth en NBER working paper series. Cambridge, MA.

Barnett M. L., Darnall N., and Husted B. W. 2014 Sustainability strategy in constrained economic times en Elsever Ltd, ScienceDirect.

Braudel, F. 1986. La dinámica del capitalismo. Fondo de Cultura Económica, México D.F. 48 p. 
Coddington, W. 1993. Environmental marketing's new relationship with corporate environmental management. In: Environmental Quality Management Vol. 2, No.3, Revisado el 04 de abril de 2015 En: http://onlinelibrary.wiley.com.sci-hub.org/ doi/10.1002/tqem.3310020310/abstract. pp: 297-302.

Coddington, W. 1993. Environmental marketing's new relationship with corporate environmental management. In: Environmental Quality Management Vol.2, No.3, Revisado el 04 de abril de 2015. En http://onlinelibrary.wiley.com.sci-hub.org/ doi/10.1002/tqem.3310020310/abstract. pp: 297-302.

De la Cruz R, S., Gómez T. L., Gómez C. M. A., y Schwentesius R, R. 2012. Regulación y normatividad de la agricultura orgánica en México y en el mundo en: Competencia y dinámicas de ajuste en la horticultura. Universidad Autónoma de Sinaloa. Coordinadores: Gaxiola C., H., E., Schwentesius R., R., Gómez C., M. A., Avendaño R., B., D., y Trujillo F., J., de D. México D.F.

Escalona, A. M. A. 2009. Los tianguis y mercados locales de alimentos ecológicos en México: su papel en el consumo, la producción y la conservación de la biodiversidad y la cultura. Tesis doctoral. Universidad de Córdoba, España. 420 p.

Frisk, G. 1973. Criteria for a theory of responsible consumption. In: The Journal of Marketing, Vol. 37. No. 2. pp: 24-31.

Fuller, D. A. 1999. Sustainable marketing: Managerial-ecological issues. Sage Publications, Inc. California. 395 p.

García B. R. 2015. Tianguis alternativos locales en México, como puntos de encuentro micropolítico: en la búsqueda de posibilidades de vida en el presente. Tesis doctoral. Benemérita Universidad Autónoma de Puebla, Facultad de Economía. Puebla, Pue. 261 p.

Gómez C.M.A., Schwentesius R.R., Ortigoza R.J., Gómez T.L., May T.V., López R. U.I., Arreola Q.J.A., y Noriega A. G. 2010. Agricultura, Apicultura y Ganadería Orgánicas de México 2009. Estado actual-Retos-Tendencias. Universidad Autónoma Chapingo (UACh) Centro de Investigaciones Interdisciplinarias para el Desarrollo Rural Integral (CIIDRI). Chapingo, Estado de México, Octubre.

Gómez, T. L., Martin, L., Gómez C, M, A., and Mutersbaugh T. 2005. Certified organic agriculture in Mexico: Market connections and certification practices in large and small producers. In: Journal of Rural Studies Vol. 21, No.4. pp: 461-474.

Gómez, T, L., y Gómez, C. M. A. 2004. La agricultura orgánica en México: Un ejemplo de incorporación y resistencia a la globalización. Revisado 14 de agosto de 2014 en http://dlc.dlib. indiana.edu/dlc/handle/10535/1679

Gómez. P. A. 2000. Agricultura orgánica: una alternativa posible. Programa de agroecología, documentos CEUTA. Domínguez, A., y Prieto, G., R., (coords). In: Perfil ambiental del Uruguay NORDAN. Montevideo, Uruguay. pp: 14-30.

IFOAM. 2008. Sistemas Participativos de Garantía: Estudios de caso en América Latina. International Federation of Organic Agriculture Movements (IFOAM), Alemania.

Källander, I., y Rundgren G. 2009. Construyendo sectores orgánicos sustentables. International Federation of Organic Agriculture Movements (IFOAM), Alemania.

Kilcher L., Willer H., Huber B., Frieden C., Schmutz R., and Schmid O. 2011. The Organic Market in Europe: Overview and market Access Information for Producers and International Trade of Companies. Fourteen Country Examples in the European Free Trade Association and the European Union, with a Special Focus on Switzerland. 3era ed. SIPPO and FiBL, 268 p.
Nelson, E., Schwentesius R.R., Gómez T. L., y Gómez C. M. A. 2007. Experiencias de la Red Mexicana de Tianguis y Mercados Orgánicos: el nacimiento de un movimiento orgánico local en México. En http://www.tianguisorganicos.org.mx/wp-content/ uploads/2012/07/ExperienciasREDAC.pdf

Peattie, K., y Ratnayaka M. 1995. Responding to the Green movement. In: Industrial Management Vol. 21, New York, NY. pp:103-110.

Polonsky, M. J. 1994. An introduction to Green marketing. In: Electronic Green Journal Vol. 1, No. 2. pp: 1-10.

Prakash A. 2002. Green marketing, public policy and managerial strategies. In: Bussines Strategy an Environment Vol. 11, No. 5. pp: $285-297$.

REDAC. 2013. Antecedentes. Revisado en mayo de 2013 http:// tianguisorganicos.org.mx/antecedentes/.

Rendón, M. R. 2004. Evaluación comparativa de sustentabilidad en sistemas agrícolas convencionales, mixtos y orgánicos de México. Tesis doctoral; Universidad Autónoma Chapingo, Centro de Investigaciones Económicas, Sociales y Tecnológicas de la Agroindustria y la Agricultura Mundial (CIESTAAM), Chapingo, Estado de México, agosto.

Sáenz, D. A. M. 2009. La agricultura y su evolución a la agroecología. Obra propia Editorial. España.

Sarandón, S, J. 2002. El desarrollo y uso de indicadores para evaluar la sustentabilidad de los agroecosistemas. In: Agroecología. El camino para una agricultura sustentable. pp: 393-414.

Sarandón, S, J., Zuluaga M. S., Cieza R., Gómez C., Janjetic L., y Negrete E. 2008. Evaluación de la sustentabilidad de sistemas agrícolas de fincas en Misiones, Argentina, mediante el uso de indicadores. In: Agroecología, 1. pp: 19-28.

Schwentesius, R. R., Gómez, C., M. A., y Nelson E. 2013. La Red Mexicana de Tianguis y Mercados Orgánicos- México: Renovando sistemas de abasto de bienes de primera necesidad para pequeños productores y muchos consumidores. In: Sistemas Participativos de Garantía: Estudios de caso en América Latina. International Federation of Organic Agriculture Movements (IFOAM),

Shil, P. A. 2012. Evolution and future of environmental marketing. In: Asia Pacific Journal of Marketing \& Management Review Vol. 1 No. 3, pp: 74-81.

Smith, A. 1988. Investigación sobre la naturaleza y causas de la riqueza de las naciones. Editorial, Oikos-Tau, Barcelona, Espańa, pp: 95-106.

SOCLA and TWIN. 2015. Agroecology: Key concepts, principles and practices. Jutaprint, Malaysia. $52 \mathrm{p}$.

Solow, R. M. 1991. Sustainability: an economist's perspective en la Lectura 18 de J. Seward Johnson, para el Centro de la política marítima, Woods Hole Oceanographic Institution en Woods Hole, Massachusetts, Junio.

Soto, G. 2003. Memoria del taller: Agricultura orgánica; una herramienta para el desarrollo rural sostenible y la reducción de la pobreza. Texto: Expositores y organizadores del taller. Elaboración: Gabriela Soto, coordinadora del taller Turrialba, Costa Rica.

Zayas, B. R. A., Zayas B. I., y Castro M. J. A. 2012. Agricultura orgánica: alternativa del futuro para el desarrollo sustentable. In: Competencia y dinámicas de ajuste en la horticultura. Universidad Autónoma de Sinaloa, 1 era ed. Coordinadores: Gaxiola C., H., E., Schwentesius R., R., Gómez C., M. A., Avendaño R., B., D., y Trujillo F., J., de D. México. pp: 435-448. 